الأصل التعبدي للتريبة الإسلامية وتطبيقاته التريوية

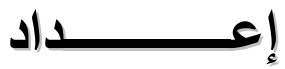

$$
\begin{aligned}
& \text { د. خولة أكرم جراح }
\end{aligned}
$$

Doi: $10.12816 / 0047765$

مجلة الدراسات التريوية والانسانية ـ كلية التربية ـ جامعة دمنهود المجلد التاسع - العدد الأول- لسنة التربة 2017 


$$
\text { الأصل التعبدي للتربية الإسلامية وتطبيقاته التريوية د. ـولة أكرم جراح }
$$




\section{الأصل التعبدي للتربية الإسلامية وتطبيقاته التربوية}

\section{د. نولة أكرم جراح}

الملخص

تتحدد أهمية البحث في اختلاف فهم الناس للعبادات، فمنهم من براها

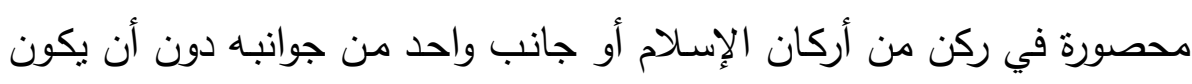

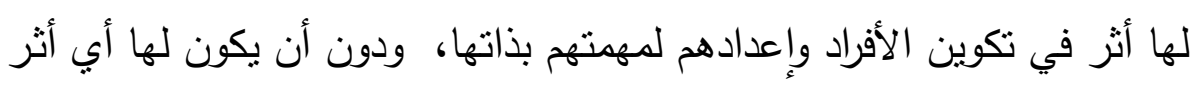

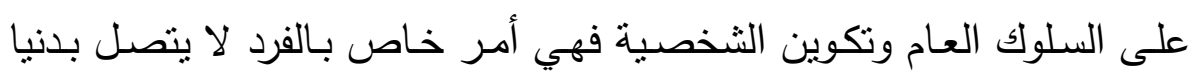

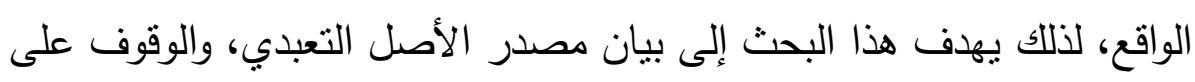

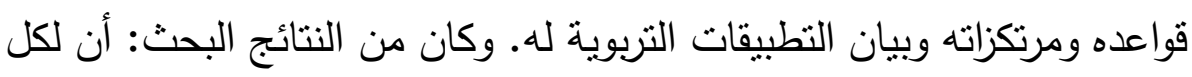
عبادة من العبادات الخمس تأثير فعال ومتوازن في النفس البشرية في جوانبهان

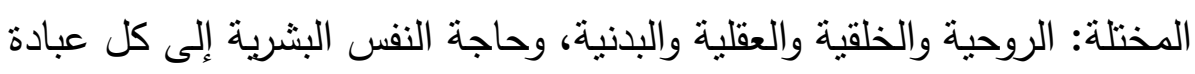

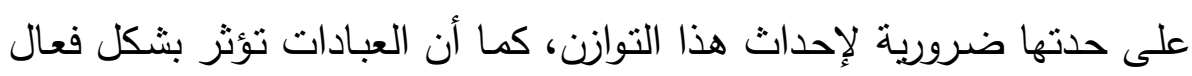

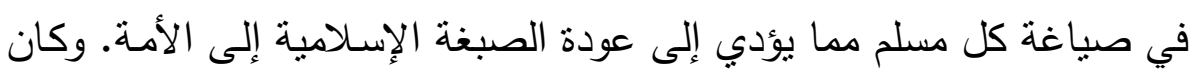

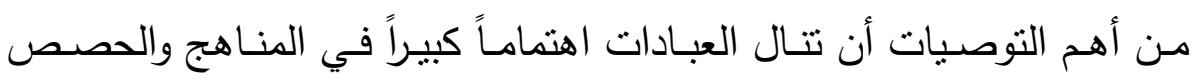

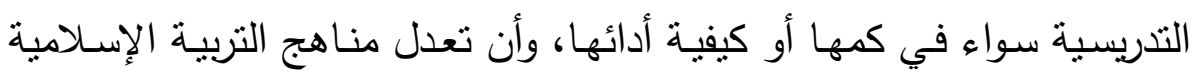

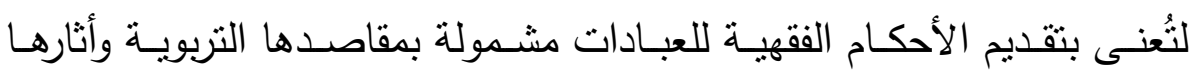

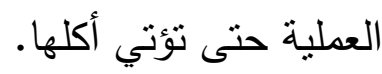




\begin{abstract}
the importance of research determines the different people's understanding of worship, some of whom see it confined to the five pillars of Islam, or by one of its aspects without having an impact in the formation of individuals and preparing them for the mission itself, without having any impact on public behavior and formation of personality is something special to the individual not related to the real life.

This research aims to indicate the source of the original worshipful, and stand on the rules and supporting infrastructure and educational applications statement to.

The research results: That every act of five worship has an effective and balanced effect on the human psyche in its dysfunctional aspects: spiritual, moral, mental and physical, and the need of the human soul to the worship Despite the cruelty necessary to bring this balance, The worship influence effectively in the formulation of every Muslim which leads to the return of the Islamic character of the nation.

One of the most important recommendations to undermine worship a great interest in teaching curricula and teaching classes and to modify the Islamic education curricula concerned with providing doctrinal provisions of the Worship Include educational purposes and practical implications.
\end{abstract}




\section{المقدمة:}

لا تتـظم الحيـاة مـن غير مـنهج ينظم مسـيرة النـاس ويحدد خطواتهم والإسـام يحدد هذا المنهج؛ وذلك لإحتواءه على جميع المكونـات التي تحدد

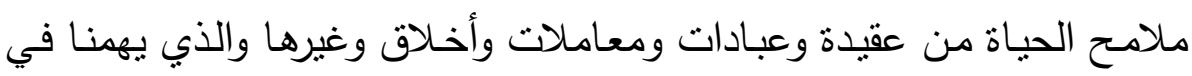

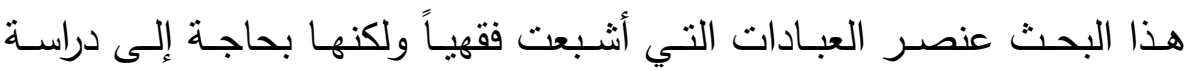
تربوية؛ وذللك لارتباطها الوثيق بالتربية الإسلامية ـ

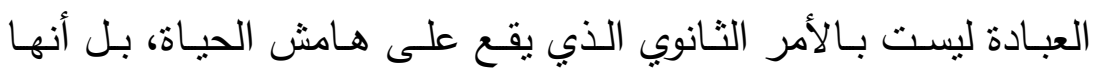

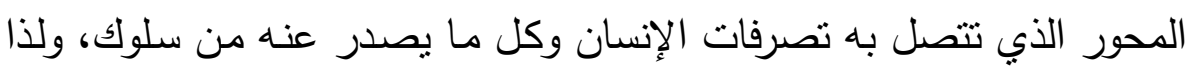

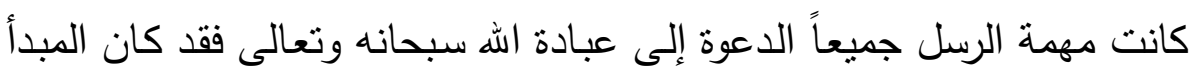

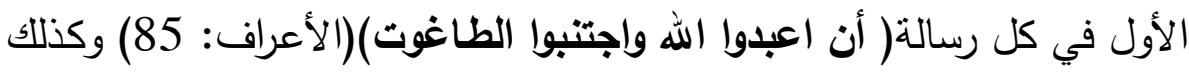

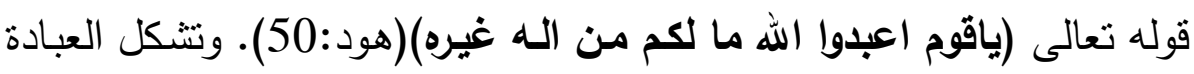

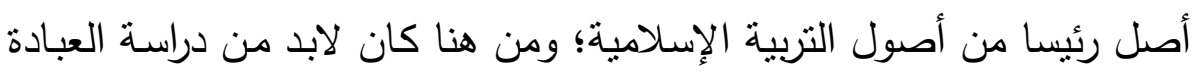

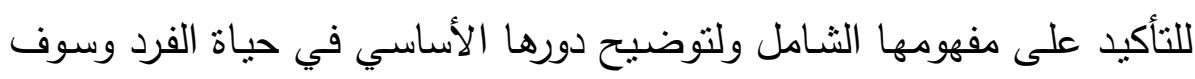
يركز هذا البحث على إبراز مرتكزات هذا الأصل والدور التربوي لهذا الأصل مله في صقل وتتمية وتوجيه العملية التربوية.

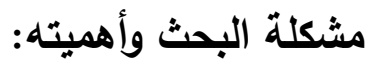

يختلف فهم الناس للعبادات، فمنهم من يراهـا محصورة في ركن من

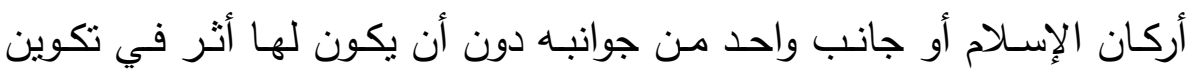

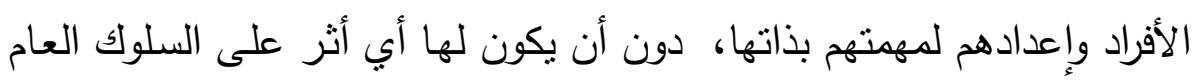

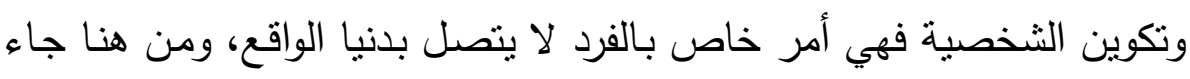

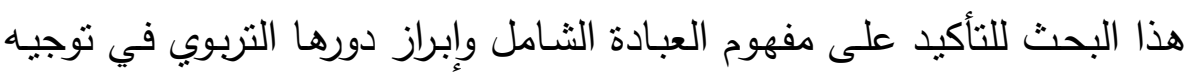
السلوك الإنساني من خلال تحقيق الأهداف التالية: 1- الوقوف على مفاهيم البحث وبيان معانيها التفصيلية. 2- الوقوف على مصادر الأصل التعبدي. 


\section{الأصل التعبدي للتربية الإسلامية وتطبيقاته التربوية د. خولة أكرم جراح}

3- الوقوف على قواعد ومرتكزات الأصل التعبدي.

4- الوقوف على النطبيقات التربوية للأصل التعبدي.

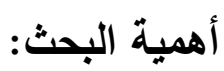

تتبع أهمية هذا البحث من الأبعاد التالية:

1- قلة الأبحاث المتعلقة بالجوانب التربوية للأصل التعبدي،وحاجة المكتبات الابعاد إلى منل هذه الدراسات.

2- هذه الدراسة مصدر للباحثين والمربين ودعاة ومخططي المناهج والمرتمين بالعملية التربوية والقائمين على عملية الإرشاد والتوجيه.

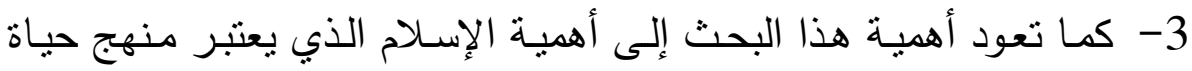

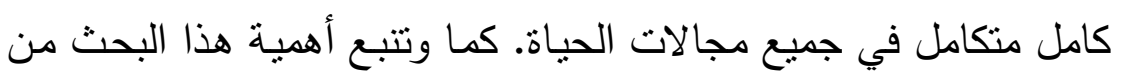

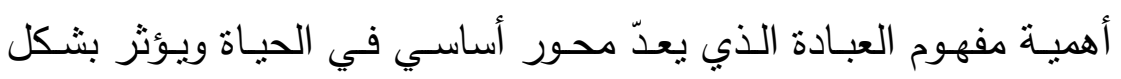
مباشر على العديد من جوانب الحياة للأفراد. منهجية البحث: مياترعي سيستخدم هذا البحث المنهج الوصفي والاستتباطي. حدود البحث:

سيقتصر هذا البحث على أصل واحد من أصول التربية الإسلامية وهو

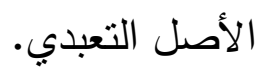

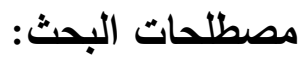
أولاً:مفهوم الأصل 
الأصل لغة: هو أسفل الثيء وأساسـه الذي يقوم عليه ومنشؤه الذين

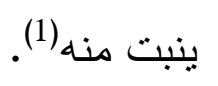

الأصل اصطلاحاً: هو المبادئ العليا التي تقوم عليها حياة الناس في

$$
\text { دينهم ودنباهم كمبدأ الحرية وغيره(2). }
$$

ويعرف أيضاً بأنه الدصدر والدليل، يقال: أصل هذه المدأن المسألة الكتاب

$$
\text { والسنة أي مصدرها ودليلها (3). }
$$

\section{ثانياً: مفهوم التربية}

التربيـة لغة:من خـال الرجوع إلى معاجم اللغة العربية تبين أن هناك

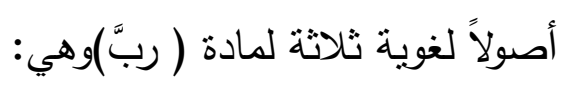

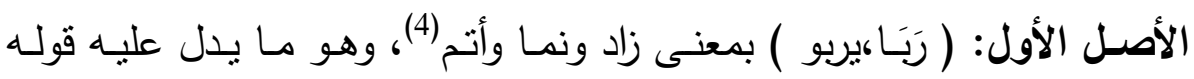

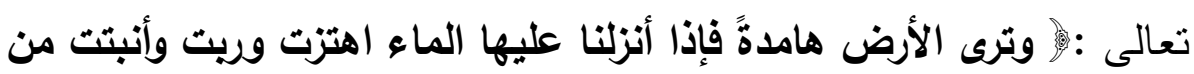

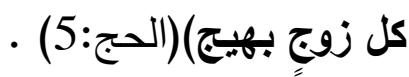

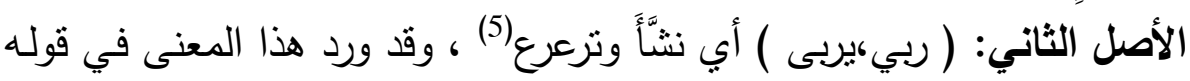

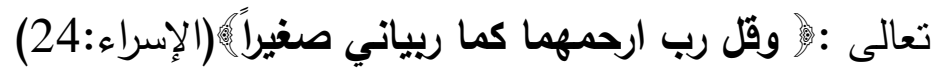

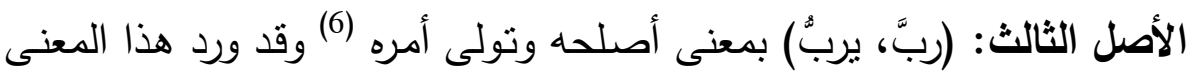

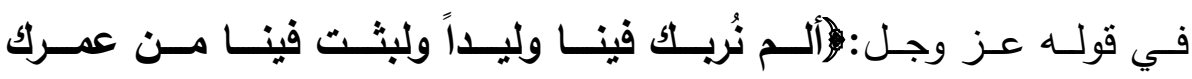
سنين)(الشعراء:18).

(1). ابن منظور ، أبو الفضل جمال الدين(1999) لسان العرب، ط3، ،دار صادر ،بيروت ج 6، ص134.

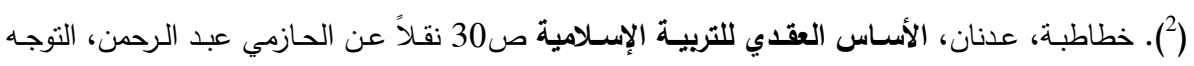
الإسلامي لأصول التربية.

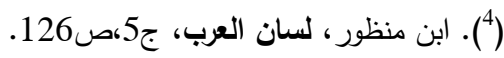

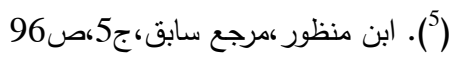




\section{الأصل التعبدي للتربية الإسلامية وتطبيقاته التربوية د. خولة أكرم جراح}

وهذا يعني أن كلمة التربية لا تخرج في معناها اللغوي عن دائرة النمو

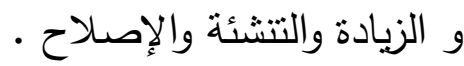

التربية اصطلاحاً:

فقد عرَّفها البيضـاوي(7) بقولـهـ :" الـرب في الأصـل مصدر بمعنى

التربية .وهي تبليغ الثيء إلى كماله شيئاً فثنيئًا ".

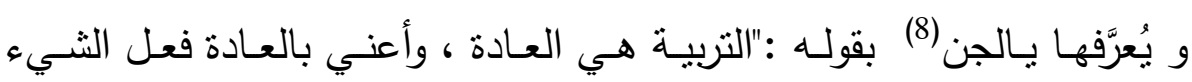
الواحد مراتٍ كثيرةً ، وزماناً طويلاً في أوقاتٍ هُتقاربـة " . كما أنها أورد تعريفاً

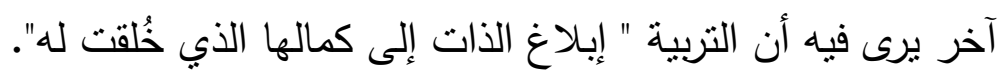

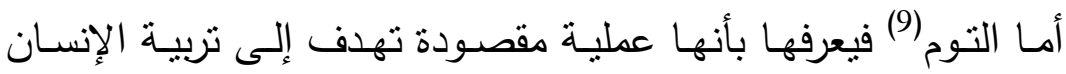

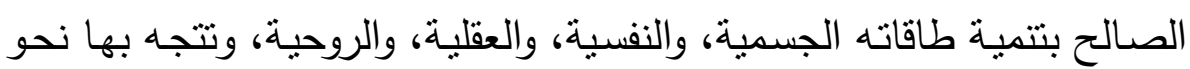
الأفضل والأكمل،وتهدف كذلك إلى تتمية المجتمع والنهوض بـه، بتلبية حاجاته

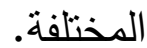

ثالثاً: مفهوم أصول التربية كل ما نستتد إليه التربية من مبادئ ومفاهيم وأساليب نظرية وتطبيقية

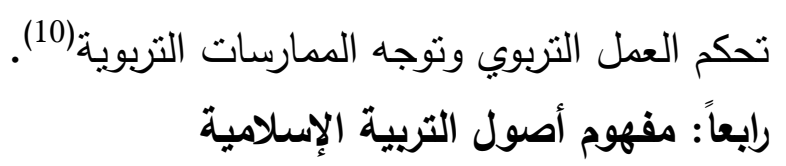

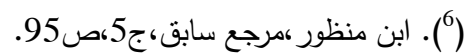

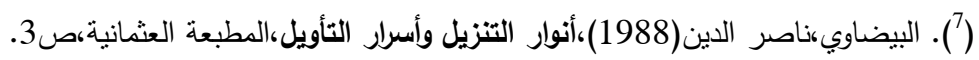

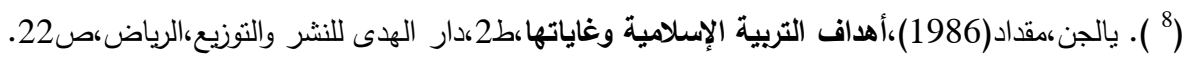

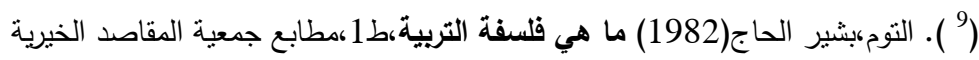

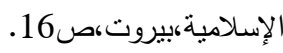
(8) (10). مرسي، محمد، أصول التربية، عالم الكتب، ص33 
هي خطوط عريضة توجه التربية وأهدافها ومناهجها ووسائلها، وتسمح

بالاجتهاد ومسايرة النطور وتلبي حاجات المجتمع (11).

خامساً: مفهوم العبادة

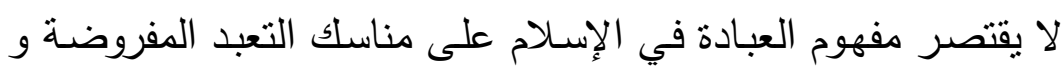

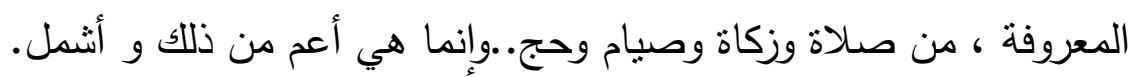

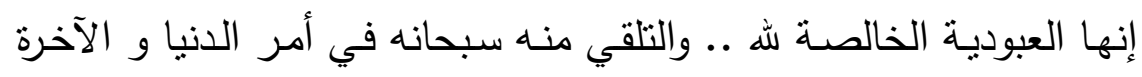

.ثم هي الصلة الدائمة باله في هذا كله....

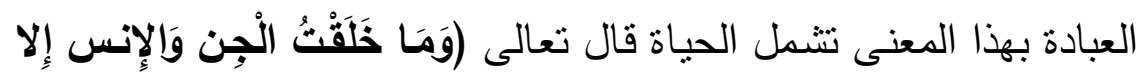

$$
\text { لِيَعَبُدُونِ)(الذاريات:56). }
$$

العبادة لغة: من الفعل الثلاثي عبد بمعنى الطاعة والتذلل والحبـ. العبادة اصطلاحاً: اسم جامع لكل مـا يحبـه الله ويرضـاه من الأقوال

والأعمال الباطنة والظاهرة(12).

وسـميت العبـادات بهـذا الاســم لأن المكلفين يلتزمـون بهـا ويؤدونهـا

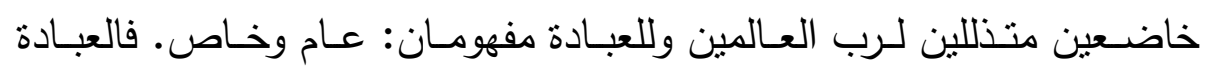

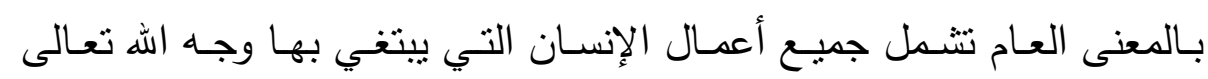
ويدخل فيها جميع ما يمارسه المسلم بنية العبادة.

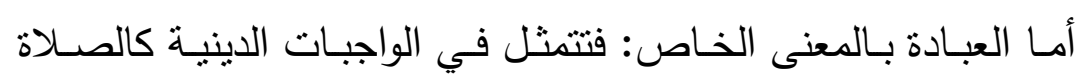

$$
\text { والصيام والزكاة والحج وغيرها. }
$$

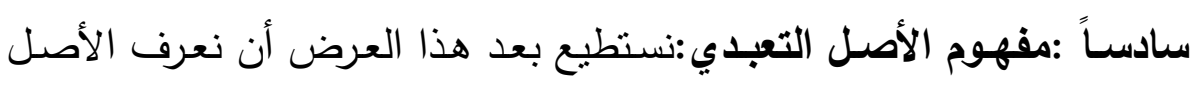

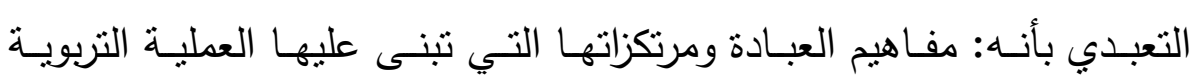
الإسـامية.(قواعد ومرتكزات العبادة التي جاء بها الإسـلام والتي تنبنى عليها

العملية التزبوية).

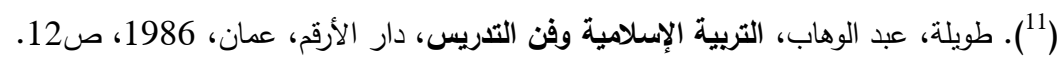

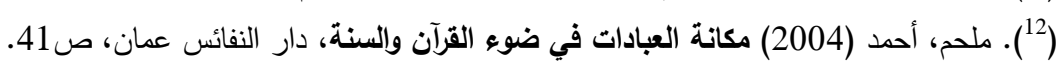


سـابعاً: مفهوم التربيـة الإســلامية:انطلاقاً من الاختلاف بين المهتمين في

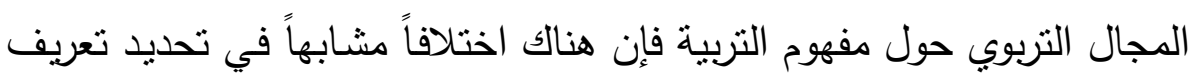

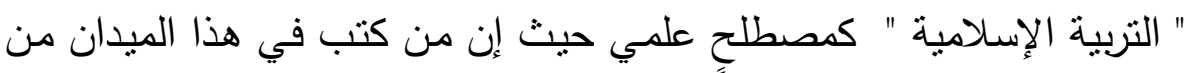

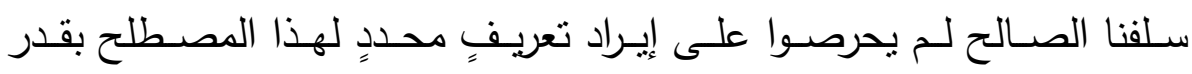

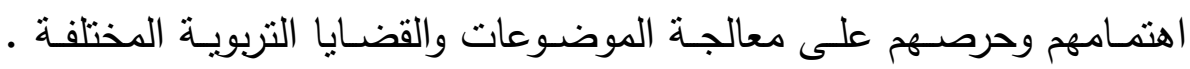

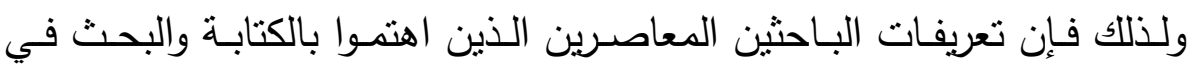

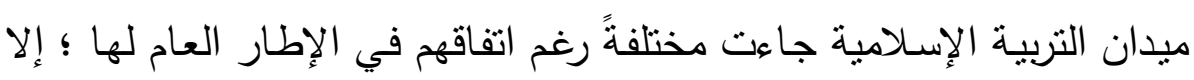

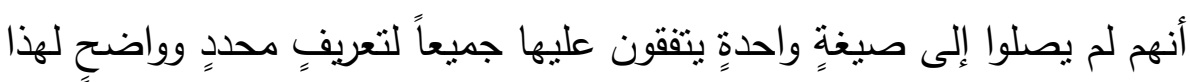

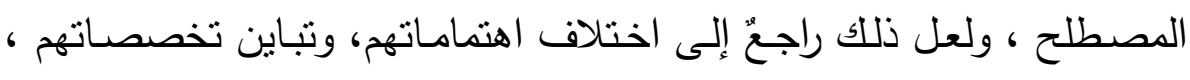
وتعدد وجهات نظرهم التقصيلية ـ وهو ما يُمكن أن نلحظه في عرضنا التالي

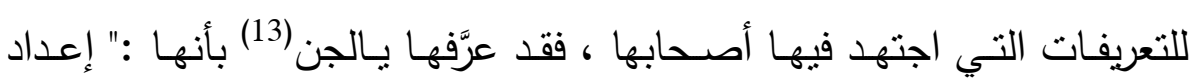

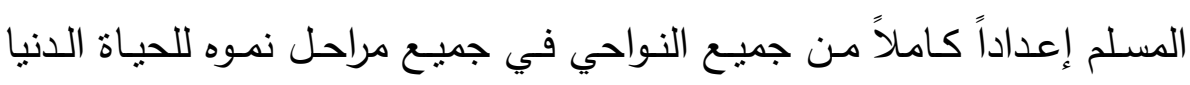

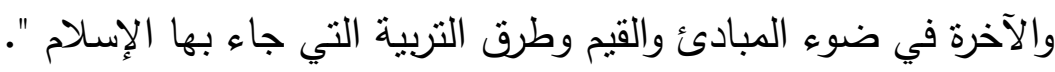
وعرَّفها زغلول(14) بأنها :" النظام التربوي القائم على الإسلام بمعناه الثامل ".

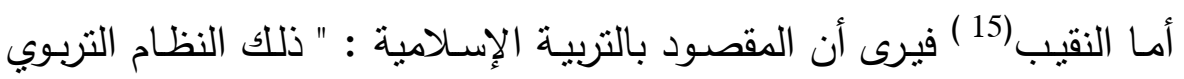

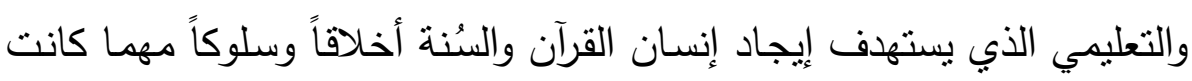
حرفته أو مهنته ".

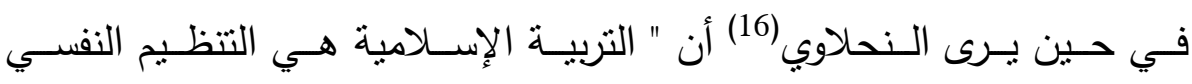

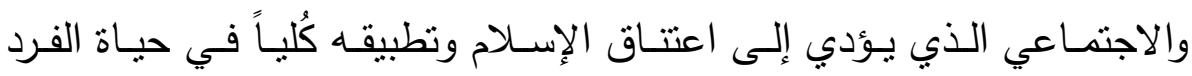

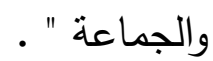

(13)

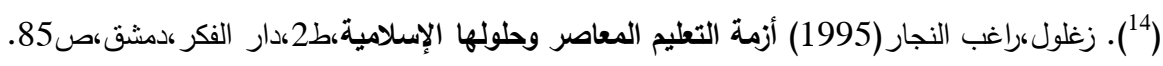

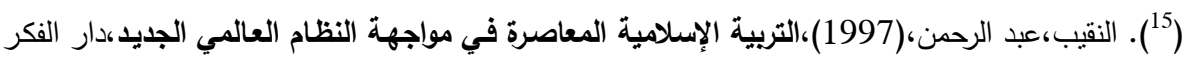


أمـا الدغشي (17)فقد عرفهـا بأنهـا عمليـة إعـداد مـنظم شــامل متكامـل للفـرد والمجتمع، من جميع الجوانب الروحية والعقلية والنفسية والجسمية للحياة الدنيا

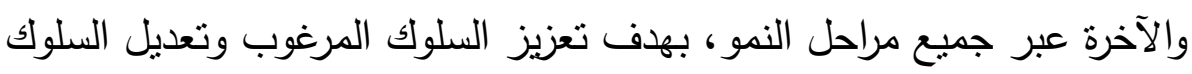
غير المرغوب، وذلك في إطار النظام الإسلامي الثامل.

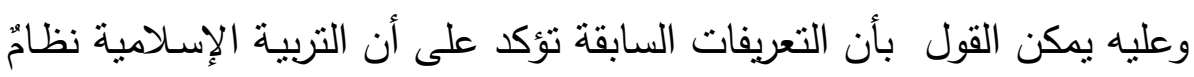

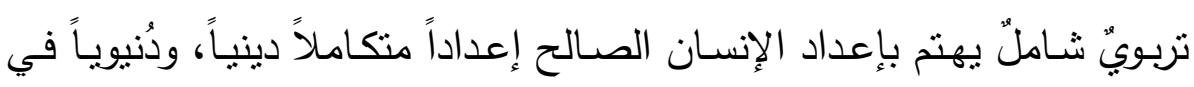
ضوء مصادر الثريعة الإسلامية الرئيسة.

المبحث الأول: المصدر الأساسي للعبادات

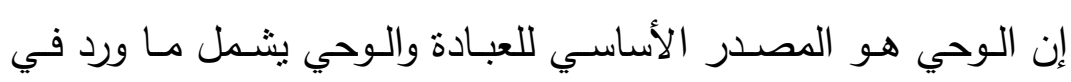

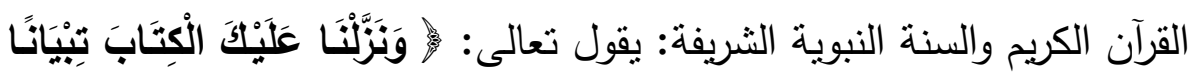

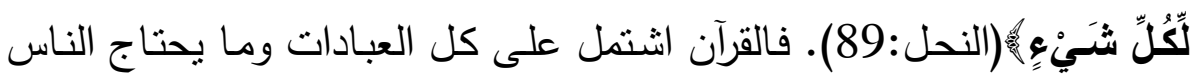

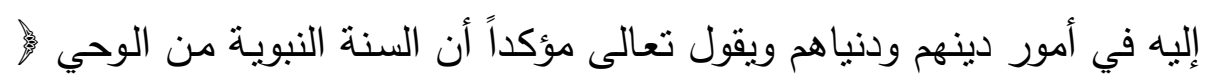

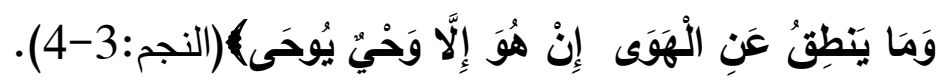

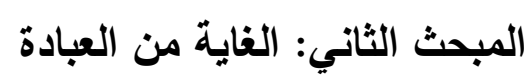

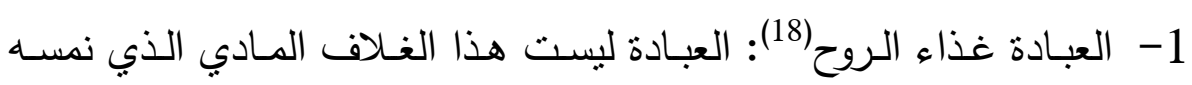
ونراه. ولكن الإنسـان هو ذلك الجوهر النفسي الذي بـه صـار الإنسـان

(16). النحلاوي عبد الرحمن ، ( 21979) أصول التربيـة الإسـلامية وأسـاليبها ، ط 2 ، دمثق : دار الفكر

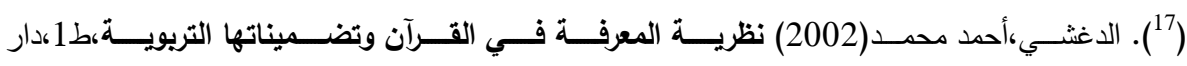

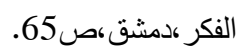
(18). القرضاوي، يوسف (1977)، العبادة في الإسلام، مؤسسة الرسالة، ط5، بيروت، ص97. 
مكرماً وسيد. ذلك الجوهر هو الروح الذي يجد حياته وزكاته في مناجاة الله عز وجل وعبادة الله هي التي توفر لهذا الروح غذاؤها.

2- العبودية لله سبيل الحرية: فالعبادة وحدها تعتق القلب من رق المخلوقات

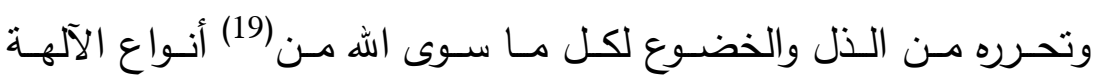
والطواغيت التي تستعبد الناس.

3- العبادة حق الله على عباده: وليس بمستتكر أن يكون لله علينا حق عبادته

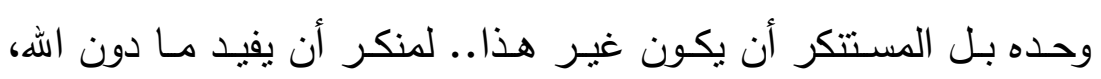

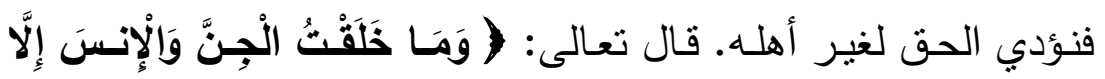

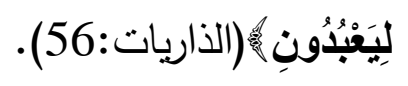

4- العبادة جلباً للثواب وخوفاً من العقاب. أي طلباً للجنة ومأمن من النار .

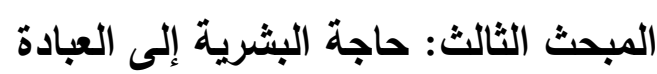

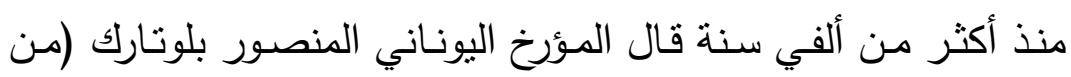

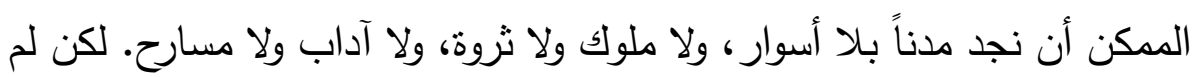
ير إنسان قط مدينة بلا معبد، أو لا يمارس أهل العبادة) (20).

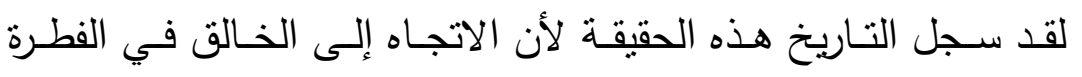

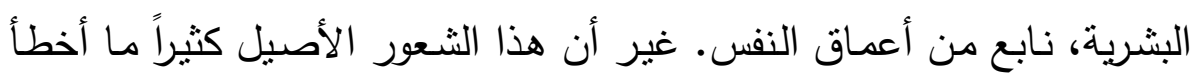

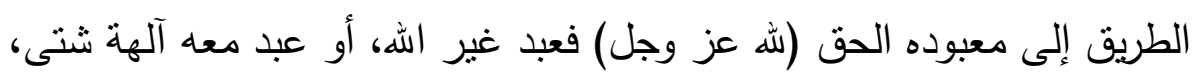

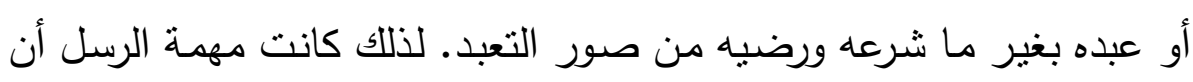

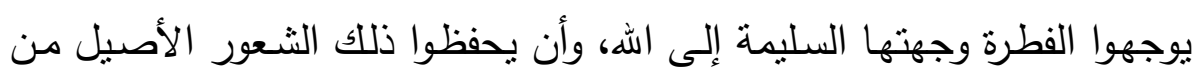
الأغراق حتى لا يعبد الإنسان إلا الله.

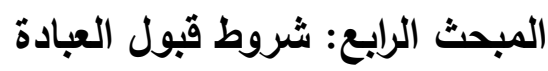




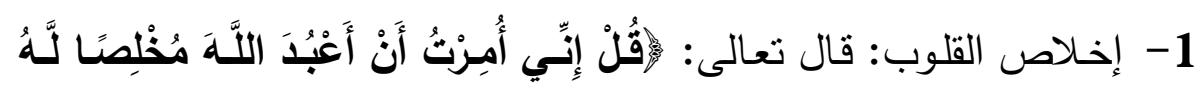

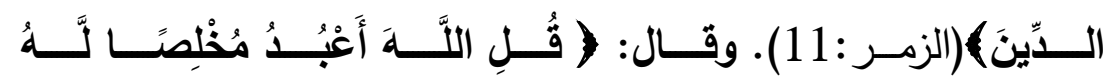

$$
\text { دينِي)(الزمر :14). }
$$

2 - لا يعبد الله إلا بما شرع: فيتبع المسلم في عباداته الحدود المرسومة له فلا

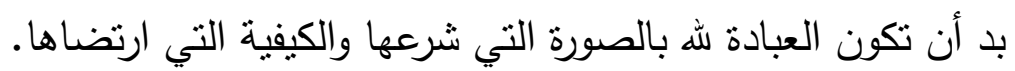
المبحث الخامس: قواعد ومرتكزات (الأصل التعبدي)

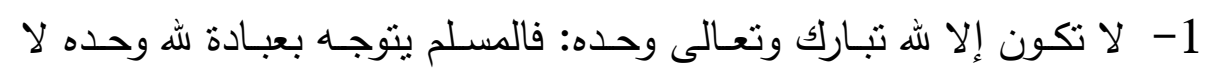

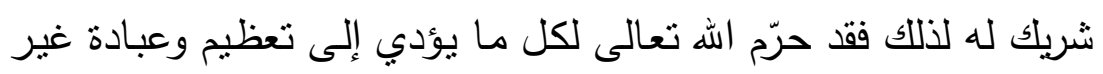
الله كالذبح لغير الله.

2- أنها خالصة لله تبارك وتعالى: فالمسلم عندما يؤدي العبادة يجب أن يقصد

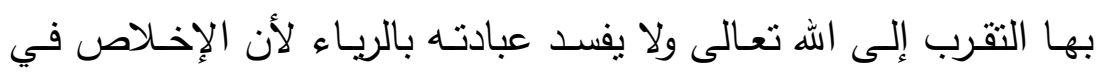

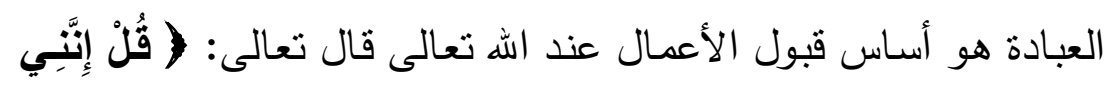

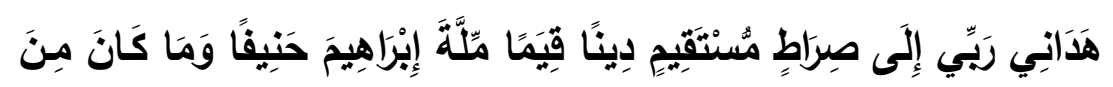

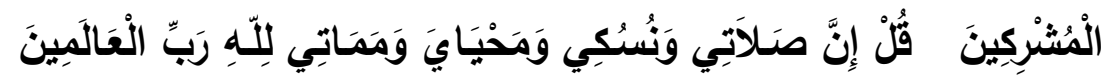

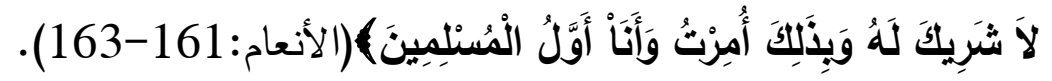
3- صلة مباشرة بين العبد وربه: فالمسلم في ممارساته للعبادات يتصل بخالقهـ

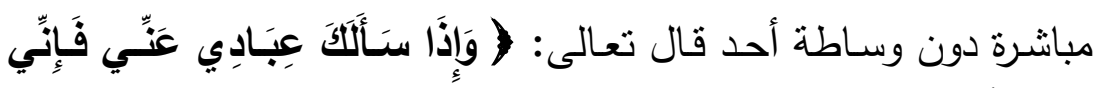

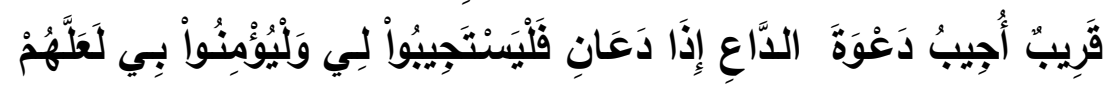

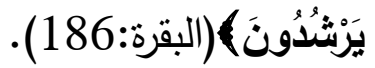

4- العبادة في الإسلام توقيفيية، يوقف بها عند الحدود التي حددها الله تبارك

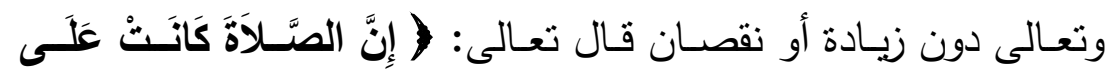

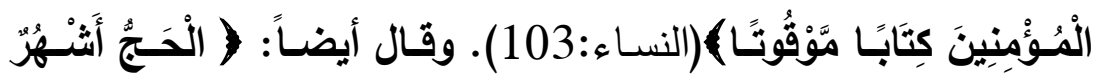

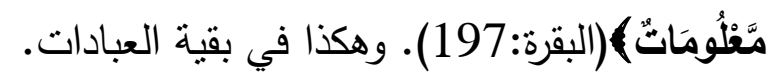
5- تقوم العبادات على التيسير ورفع الحرج. ومن مظاهر يسر العبادات: 


\section{الأصل التعبدي للتربية الإسلامية وتطبيقاته التربوية د. خولة أكرم جراح}

- - قلتها: لا نستغرق إلا جزءاً يسيراً من الوقت.

- - تشـريع الـرخص في العبـادات وذلـك في الظـروف الاسـتنثائية

كالمرض والسفر وفقد الماء وغيرها.

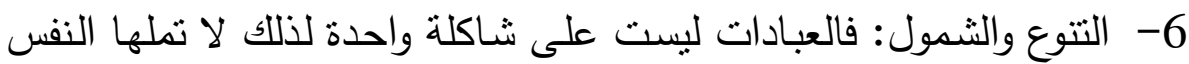

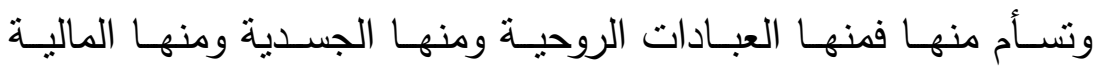

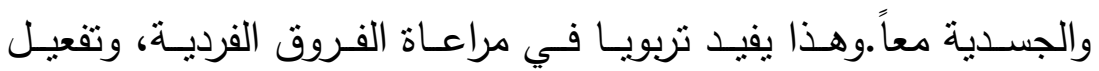

الأنشطة الامنهجية.

7- مقصودة فهي تطبيق تربوي وبدون قصد لا تعتبر عبادة.

8- العبادة حق لله وحده وهو مختص بها دون خلقه قال تعالى.

9- 9- وجوب الإتباع.

10-فردية جماعية.

11-مستمرة.

12 -لا واسطة فيها.

المبحث السابع: عبادات الإسلام وشعائره الكبرى، أسرارها وأثثارها.

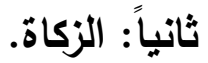

أولاً: الصلاة.

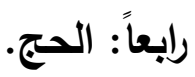

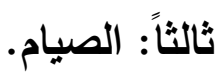

الشرح والتفصيل لهذه العبادات:

أولاً: الصلاة

الصلاة في اللغةة تعني الدعاء قال تعالى: ( وَصَلِّ عَلَيْهِهْ إِنَّ صَلَاتَكَكَ

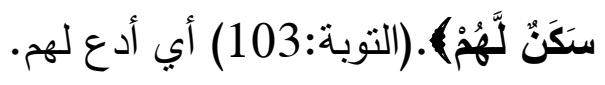

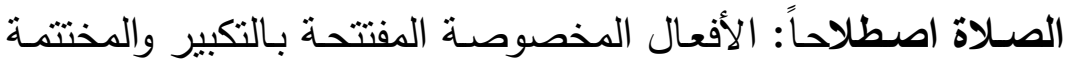

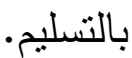

تعد الصـلاة عمود الإسـلام من العبادات المهمة التي فرضها اله على الهى

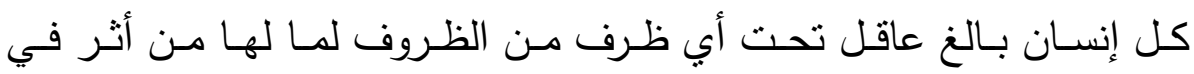


المحافظـة على الانضباط الأخلاقي الذي تحدثه هذه الفريضـة العظيمـة قال

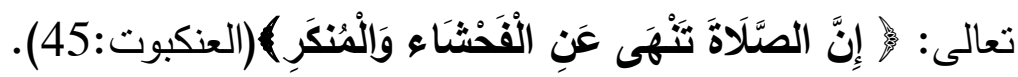

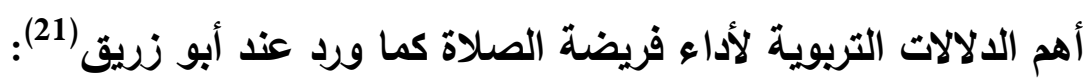

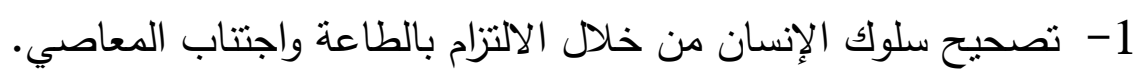

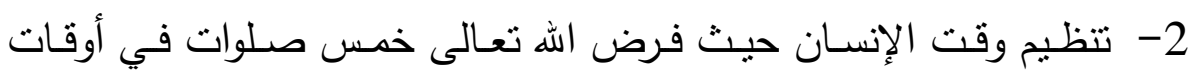
محددة مما يدفع المسلم إلى الاهتمام بالوقت.

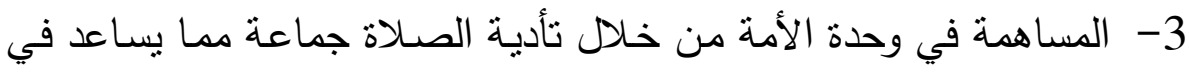
توحيد الصفوف وتقوية العلاقات بين الأفراد.

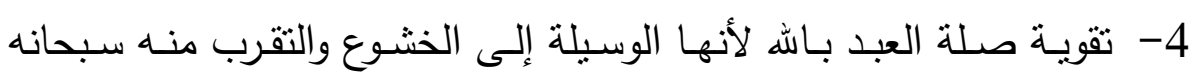
وتتعالى.

5- الصـلاة تتير الوجـه فالمصلـي مشـرق الوجـه تعلو وجهه هالـة مـن النور فتجده حسن السمت جميل المنظر .

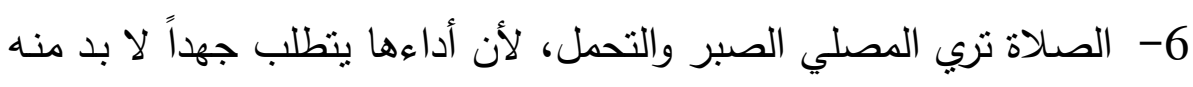
كما تعود المسلم الجد والنشاط.

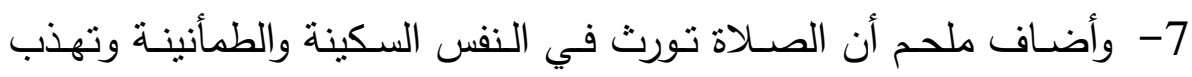
الجوارح وتغرس في نفس صاحبها مكارم الأخلاق (22). أما سلطان (23) فقد بين أن الصلاة رياضة فئن روحية للفرد فهي تجعل للمسلم

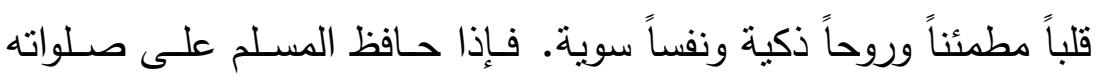
تعلق قلبه بالوقوف بين بدي ربه وتذوق حلاوة الإيمان حتى يتحول حب ولب القنوت والقيام في الليلـ إلى قوة دافعـة إلى تجافي المضـاجع وكراهيـة

(21). أبو زريق، ناصر (2002)، أصول التربية الإسلامية وأساليبها، ط1، دار البشر ، عمان، ص50.

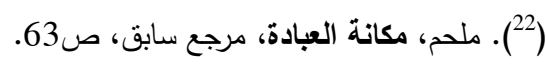
(23). سلطان، صلاح الدين عبد الحليم،(1997) ملاكؤنتمر التربوي الأول ( اتجاهات التربية وتحديات المستقبل)

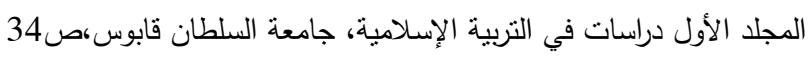


الغفلة عن التهجد في الليل. وهي أرقى صورة لحياة القلب وصفاء الروح.

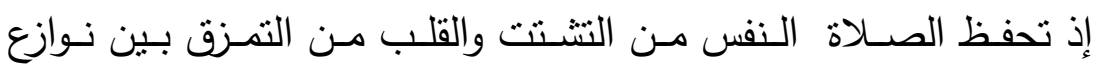
الأرض وقيم السماء. وتتحول الصلاة بعد تذوق معانيها ومعايشة آثارها إلى منهج حياة فمن احتار في قضية حسمها بصلاة الاستخارة ليمضي ولاني واثق اليقين من حسن اختيار الله له، ومن انتند به كرب هرع إلى صلاة الحاجة. وفيها دعاء القنوت يذهب عن النفس كربها ويزيل همها ويشرح

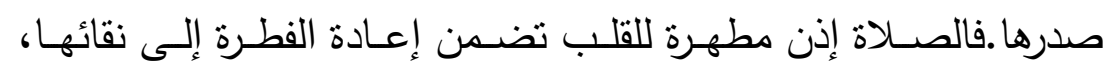
والنفس إلى صفائها، فإن أصابها كدر المعصية أو ثقل الهموم أو حيرة

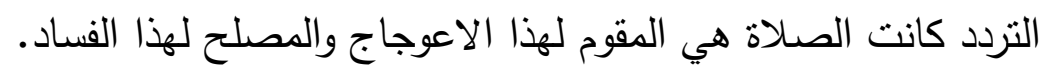

ثانياً: الزكاة

الزكاة لغة: النما والزيادة وتأتي بمعنى التطهير •

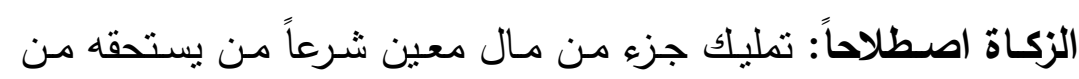

مسلم بشرط قطع المنفعة عن ذلك المال من كل وجه لله تعالى (24).

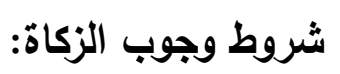

1- الإسلام: فغير المسلم يخاطب بأصل الإسلام، ثم يبني عليه كالزكاة، ولأن

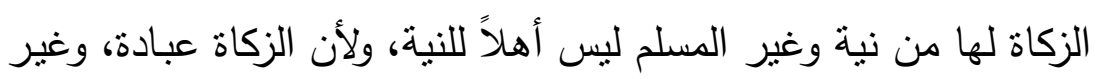

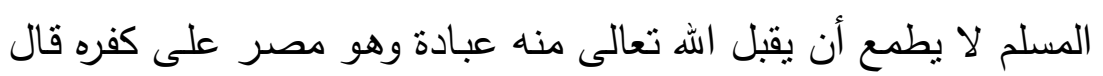

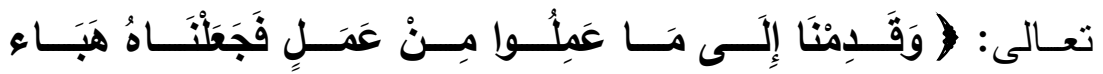

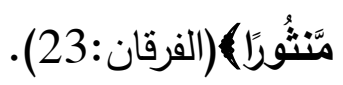
2 - الحرية: فإن كمال الملكية بالحرية، أما العبد وما ملكت بداه لسيده. 
3- ملك النصـاب: والنصساب: هو مقدار من المال المعين زائد من حوائجهـ

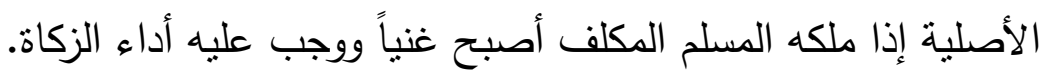
4- حولان الحول: أي معني سنة قمرية على ملك النصاب.

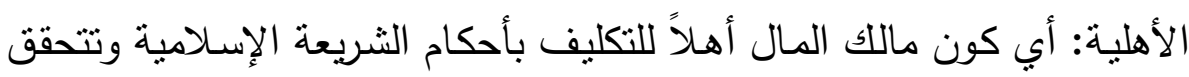
الأهلية بالبلوغ والعقل وسلامة الحواس ووصول مال الخدال الخبر إليه. الدلالات التريوية للزكاة كما ذكر القرضاوي (25): 1 - طهارة نفس الغني من الثح ونما لثخصية وكيانه المعنوي. 2- طهارة نفس الفقير من الحسرة ونماء لشخصيته حيث يحس أنه ليس

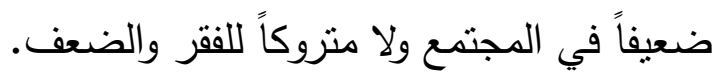

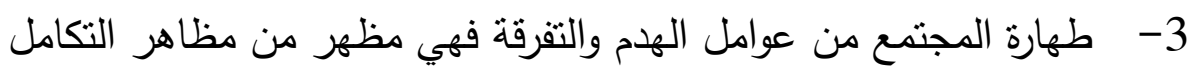
الاجتماعي.

4- طهارة للمال مما علق به من حق الغير. 5- وسيلة من وسائل الإسلام في تقريب المسافة بين الأغنياء والفقراء. 6- وسيلة لمحاربة الكفر وإخراج النقود والتثارك في ميدان العمل والتثير . أما سلطان (26) فقد ذكر بعض الآثار التربوية للزكاة في مختلف النواحي منها:

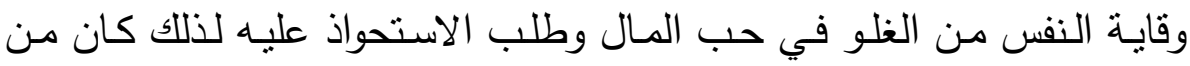

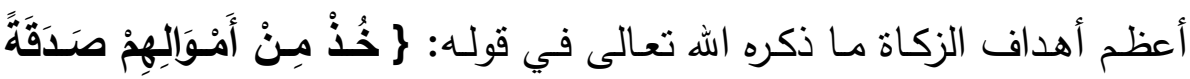

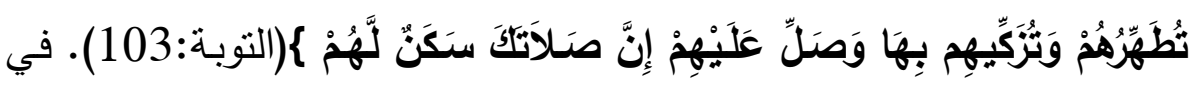
زكاة الفطر معنى اسـي فهي طهره للكبير والصغير والغني والفقير والرجل والمرأة قال صلى اله عليه وسلم (فرض زكاة الفطر طهره للصسائم من اللغو فهري

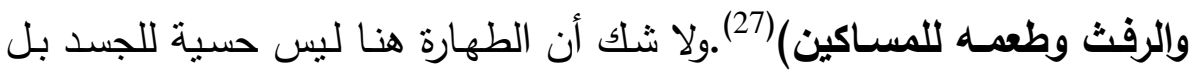




\section{الأصل التعبدي للتربية الإسلامية وتطبيقاته التريوية د. خولة أكرم جراح}

معنوية للروح. والزكاة تزكي النفس وتطهر القلب دن النهم على الدنيا وبذلك يفرغ العقل لينهل من العلم

ثالثاً: الصيام

الصيام لغة: الإمساك والكف عن الثيء.

الصيام اصطلاحاً: الإمساك عن المفطرات بنية مخصوصة من الصنية طلوع

الفجر إلى غروب الثمس.

إن للصيام فوائد كثيرة من الناحيتين الأمية والمعنوية فهو مدرسة يندرب

بها المؤمن على فضال كثيرة تحقق في مجملها معنى الثقوى الذي شرع الصوم

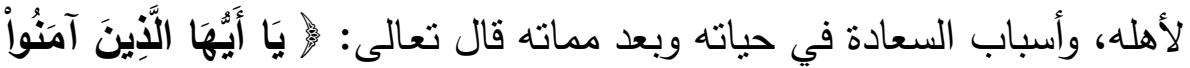

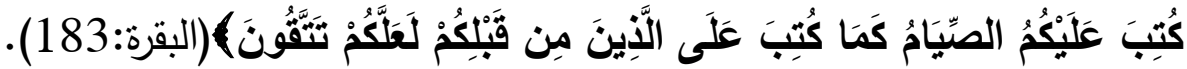

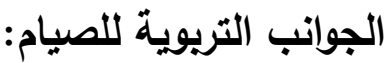

1- الصيام طاعة لله تعالى وامتثال لأمره سبحانه.

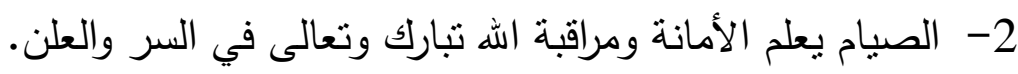

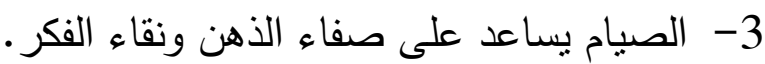

4- في الصيام صحة الأبدان، حيث تستريح المعدة والجهاز الهضمي لفترة

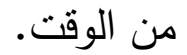

5- الصيام ينمي في الإنسان عاطفة الرحمة والعطف على الفقراء والمساكين.

$$
\text { 6- التدريب على الصبر. - - - }
$$

7- التذكير بنعم الهه علينا.التذكير بمواقف الآخرة(28).

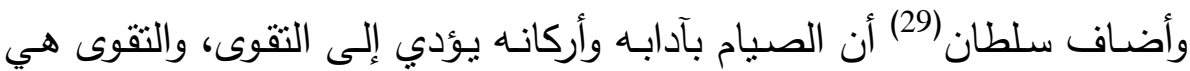

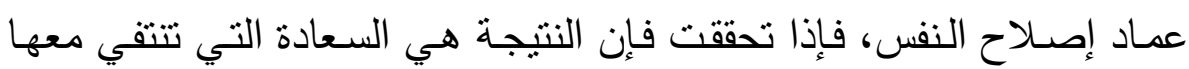

(28). التسخيري، محمد وقانصوه محمود (1995)، الصوم معطياته وأحكامه والروايات المشتركة فيه، ط1،

$$
\text { دار التقلين، ص34. }
$$

(29) (29) ـ سلطان، التربية ومستقبل الأمة، مرجع سابق،ص37

Doi: $10.12816 / 0047765$ 


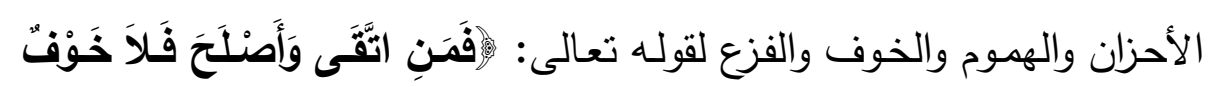

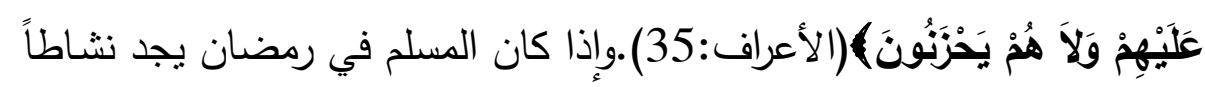

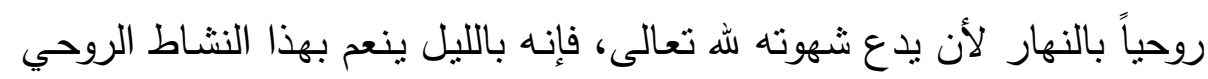

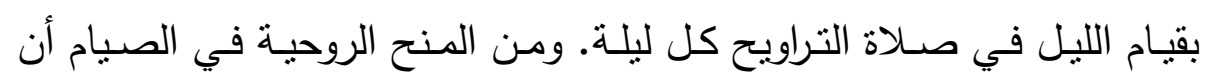

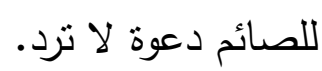
رابعاً: الحج الحج لغة: القصد.

الحج اصطلاحاً: قصد الكعبة لأداء أفعال مخصوصة.

الحج عبادة تطلب الجانب المادي والجانب الجسدي ليتمكن الإنسان لوداء

مـن الفوز ونبـل مرضـاة الله عـز وجـل وخاصـة أن هـذه الفريضــة جعلهـا الله

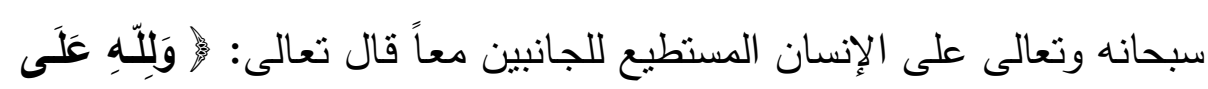

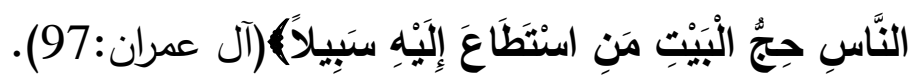
الآثار التريوية لفريضة الحج كما ذكر أبو زريق (30):

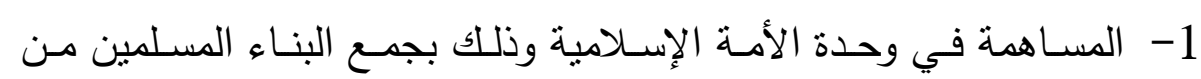

$$
\text { مشارق الأرض ومغاربها في وقت واحد وأداء شعائر واحدة. }
$$

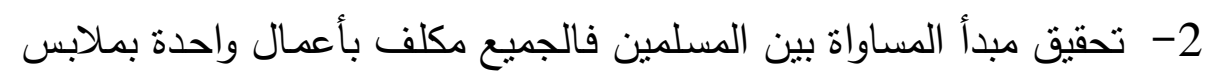
موحدة في مكان واحد لا فرق بين غني وفقير ورئيس ومرؤوس. 3- تذكير الناس بأحوال يوم القيامة والحشر بين بدي الله تعالى، عندما بقفون

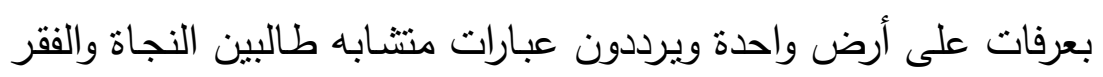
من الله تعالى. 4- تدريب الإنسان على الصبر والتحمل. نعلى 


\section{الأصل التعبدي للتربية الإسلامية وتطبيقاته التربوية د. خولة أكرم جراح}

5- اللدعوة إلى تجديد حيـاة المسلم وذلك بتجديد التوبـة وإزالـة الذنوب التي

كانت جاثمة على قلبه وتربيته على التسامح مع أفراد مجتمعه. 6- تربي المسلم على الثقة بالنفس والأمل بالمستقبل.

وقد ذكر القرضاوي(31) بعض الآثار النفسية والروحية للحج منها.

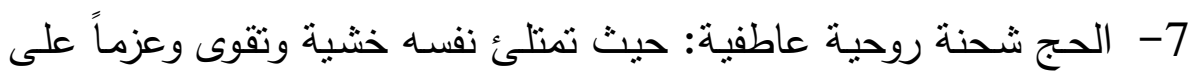
طاعة الله وندماً على معصيته. 8- الحج ثقافة وتدريب وتوسيع لأفق المسلم النقافي. 9- - المنافع التجارية في الحج. 10 10-الحج مؤتمر سنوي دعا إليه الهه العلي الكبير وهذا المؤتمر لـه أكثر من معنى فهو أما سلطان (32)فقد ذكر بعض الآثار التربوية للحج منها:

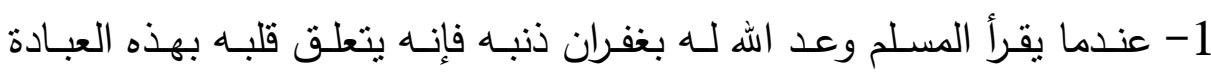
ليؤديها.

2- الحج فرصة ذهبية لإعادة القلب إلى الصفاء والنقاء والاطمئنان بذكر الله. 3- في الحج تحيا في القلب أسمى معاني الامتتال لأمر الله تعالى دون تردد بأن ما أمر الله به هو الذي يجلب سعادة الدارين.

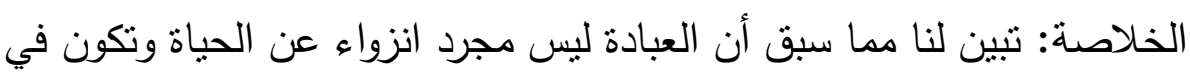

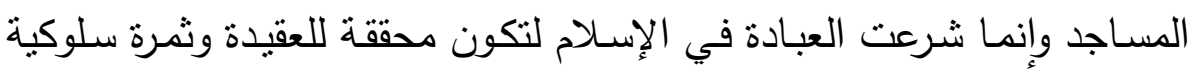
عملية لها. إن مفهوم العبادة في الإسلام يختلف عن المفهوم السائد عن الأديان الأخرى والذي كان يركز على القيام ببعض العبادات ثم يتعرف إلى السلوك 
الذي يرغب فيه دون أن يكون للعبادة أثز وانعكاس على سلوكه، فجاءت التربية

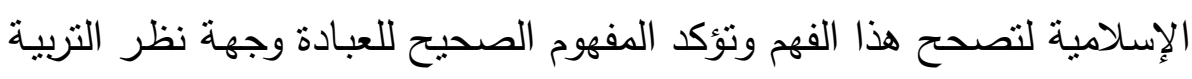

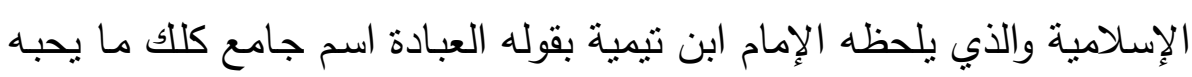

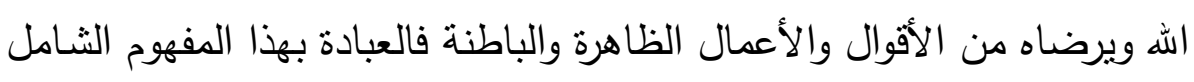

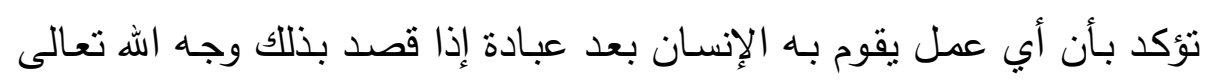

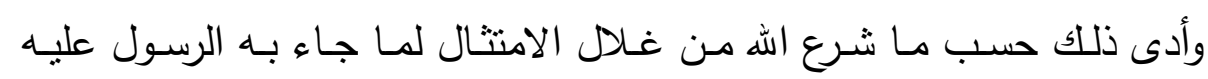

الصلاة والسلام (33).

الآثار و الفوائد التريوية للأصل التعبدي، كثيرة لارجة يصعب حصرها أو الإحاطة بها ـ وهي موجزة على النحو التالي :

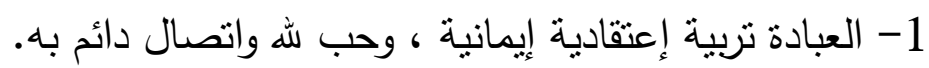
2- العبادة تتمية وتزكيه للروح ، وتوثيق لصلة الإنسان بخالقه.

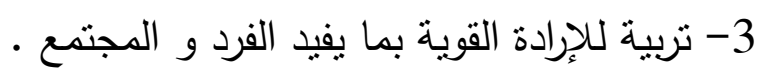

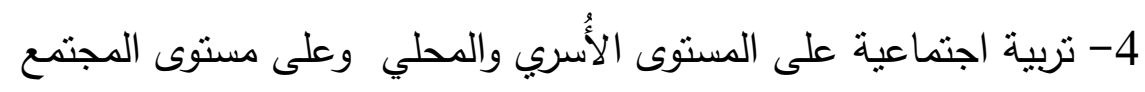
و الإنسانية . 5- تربي العبادة في الإسلام العقل وتتميه ـ فتوجهه ليتغذى بالغذاء العقلي

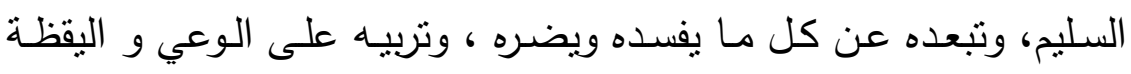
الدائمة ، وعلى التفكر في الكون والانفتاح عليه.

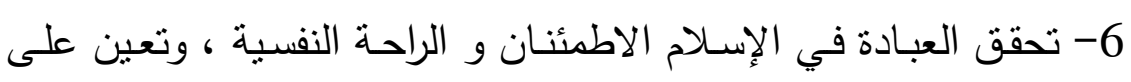
تخطي الأزمات النفسية . 7- تربيـة صحية ـ فتقوم العبادة في الإسـلام على الطهارة و النظافـة .

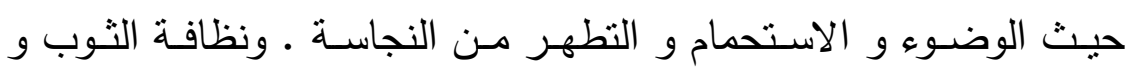

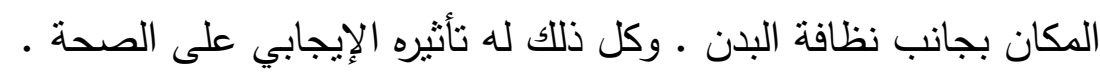


8- تربية أخلاقية .حيث تربي العبادة المسلم على قدر من الفضائل الثابتة

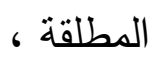

والصالحة لتربية الإنسان وبناء الإنسانية .

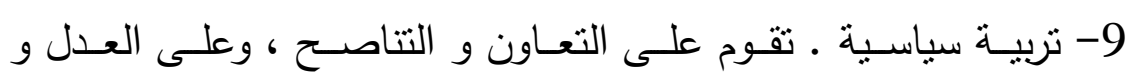
المساواة ونبذ الفرقة و التمييز العنصري ،وعلى طاعة المحكومين للحاكم

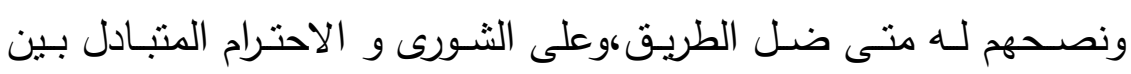

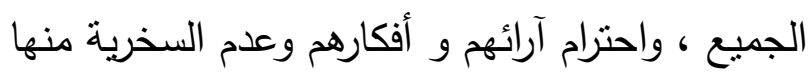

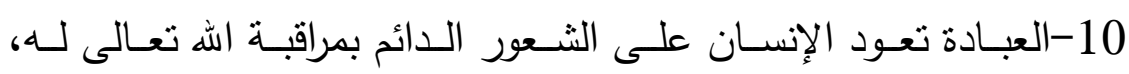
وبستشـعر عظمته في كل تصـرف فيصبح الإنسـان قوي الإرادة متحرراً مـن الإنس

عبودية الثهوة والأطماع منقناً عمله ليفوز برضا الله تعالى (34). 11- العبادة تتشـئ الإنسـان المستقيم المتوازن فكريـاً ووجدانياً، وسلوكياً،

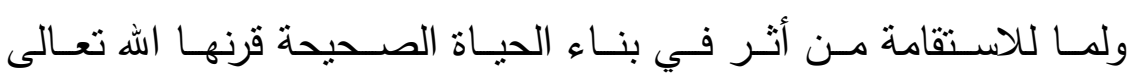
بالإيمان (35). النتائج:

1- إن لكل عبـادة مـن العبـادات الخمس ذات تأثنير فعـال ومتوازن في النفس البشرية في جوانبها الأساسية الروحية والخلقية والعقلية والبدنية.

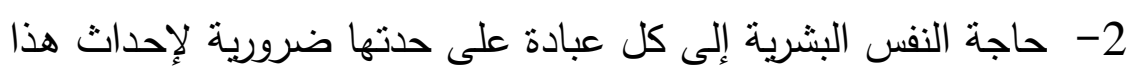

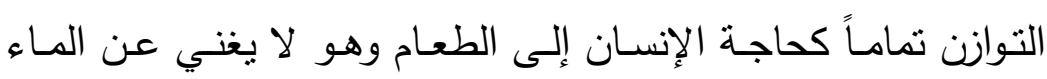

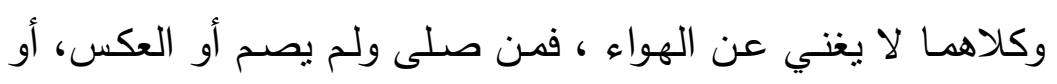

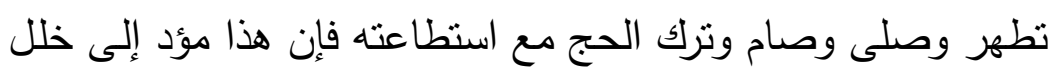
حقيقي في تكوينه الذاتي. 
3- إن هذه العبادات تسـاهم بشكل قوي في صياغة كل فرد مسلم مما

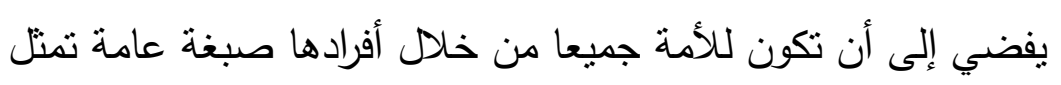

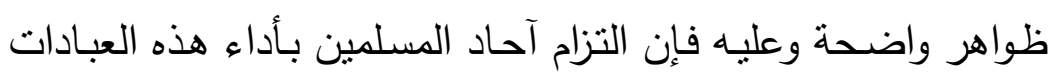

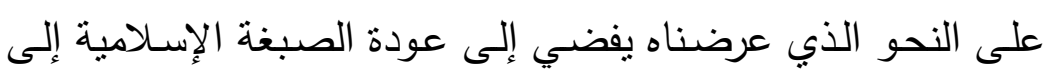
الأمة . المى التوصيات:

1- أن تتال العبادات اهتماما أكبر في المناهج والحصص التدريسية سواء في كمها أو كيفية أدائها. 2- تعديل مناهج مادة التربية الإنسلامية بأن تعنى بتقديم الأحكام الفقهية

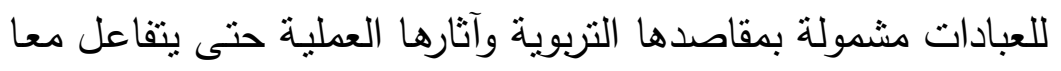
المدرس والطالب فتؤتي المادة العلمية ثمارها المعرفية والقلبية والأدائية

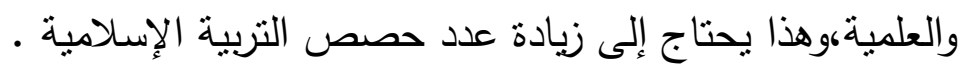

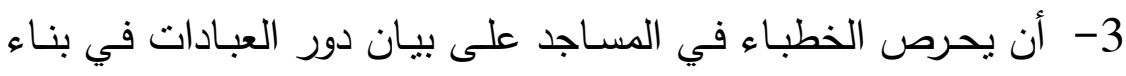

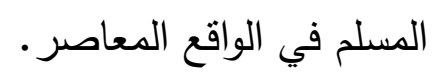


الخلاصة:

نستخلص مما سبق أن العبادة لا تقتصر على القيام بالثعائر التعبدية، لأن

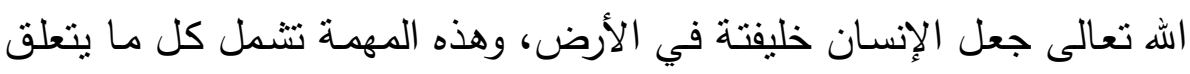
بحياة الإنسان، ونشاطاته على الأرض، وما دامت العبادة كذللك فإن من نتائج هذا أن تكون العبودية لله وحده، والتلقي في أمر الدنيا والآخرة منه وحده، وأن وندان

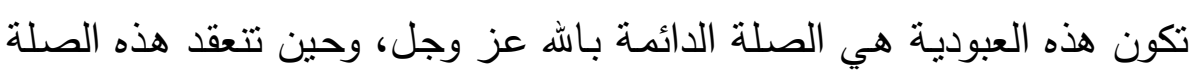

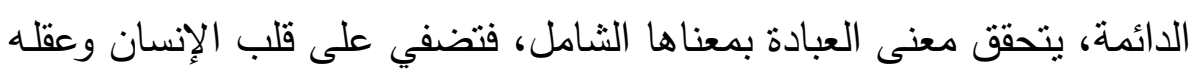

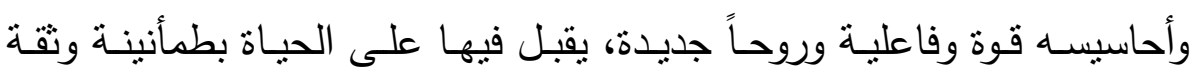

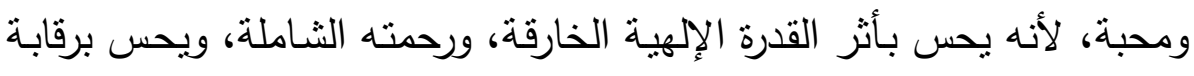

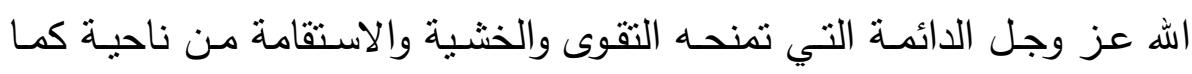

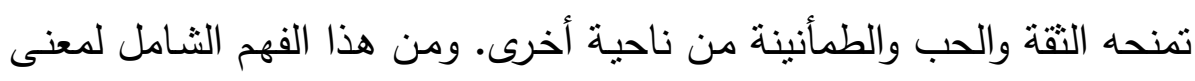

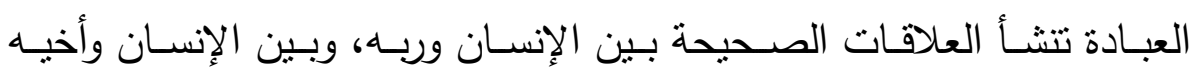

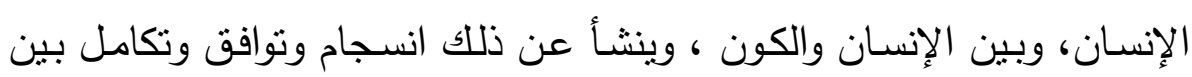
جوانبه المختلفة. 


\section{الهوامش}

1) ابن منظور ، أبو الفضل جمال الدين(1999) لسـان العرب، ط3، ،دار

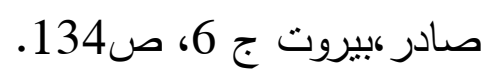

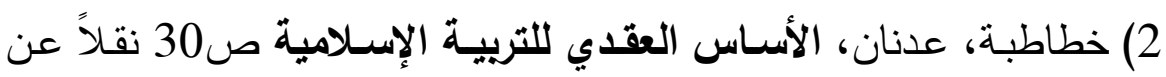
الحازمي عبد الرحمن، التوجه الإسلامي لأصول التربية.

$$
\text { 3) المرجع نفسه. }
$$

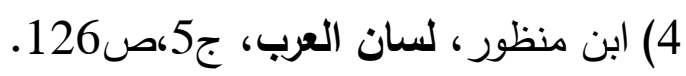

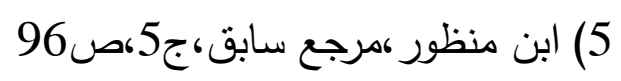

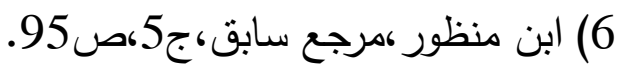

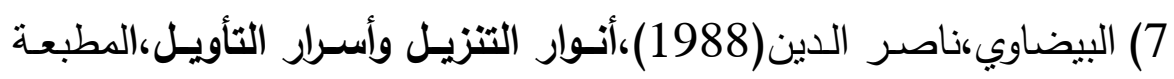

$$
\text { العثمانية،صناكن }
$$

8) يالجن،مقداد(1986)،أهداف التربيـة الإسـلامية وغاياتها،ط2،دار الهدى

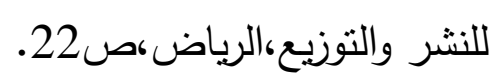

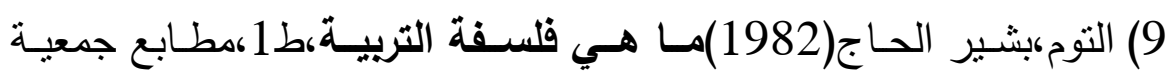

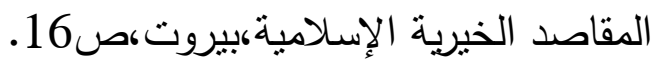

$$
\begin{aligned}
& \text { 10) مرسي، محمد، أصول التربية عالم الكتب، ص33 }
\end{aligned}
$$

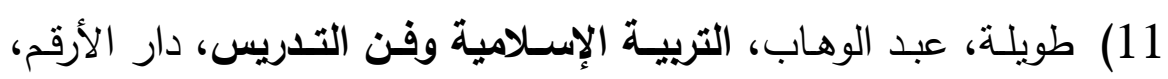

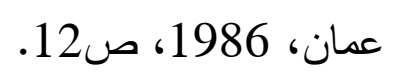

12) ملحم، أحمد (2004) مكانـة العبادات في ضوء، القرآن والسنة، دار

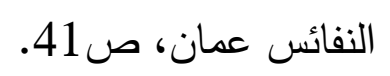

13) يـالجن، ،مقداد(1986)،أهـاف التربيـة الإســلامية وغاياتهـا،مرجـع

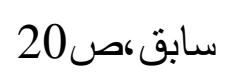

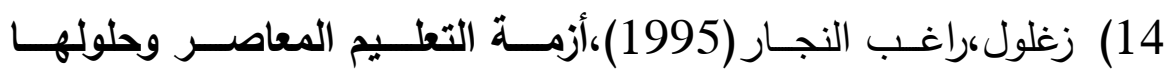

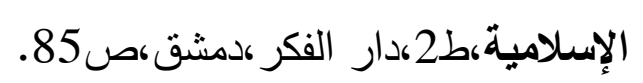




\section{الأصل التعبدي للتربية الإسلامية وتطبيقاته التربوية د. خولة أكرم جراح}

15) النقيب،عبد الرحمن،(1997)،التريية الإسلامية المعاصرة في مواجهة

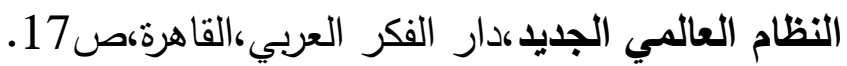

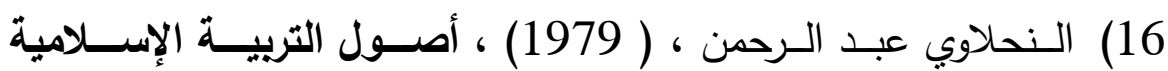
وأساليبها ، ط 2 ، دمثق : دار الفكر .صن ، 21.

17) الدغشي،أحمد محمد(2002)نظريـة المعرفة في القرآن وتضـميناتها

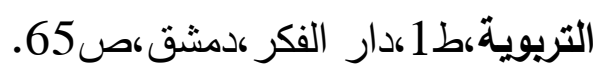

18) القرضـاوي، يوسف (1977)، العبـادة في الإسـلام، مؤسسـة الرسـالة،

$$
\begin{aligned}
& \text { ط5، بيروت، ص97. } \\
& \text { ابن تيمية، العبودية، ص108- 109 } 109 . \\
& \text { القرضاوي العبادة في الإسلام، ص131 تئه، }
\end{aligned}
$$

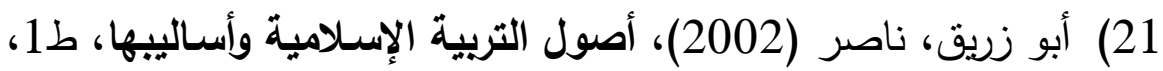

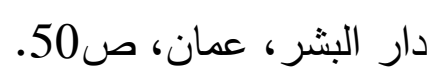

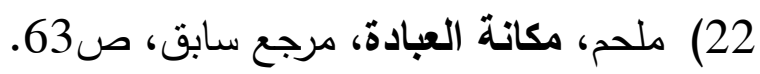

23) سـطان، صـلاح الدين عبد الحليم،(1997)(المؤتنمر التربوي الأول (

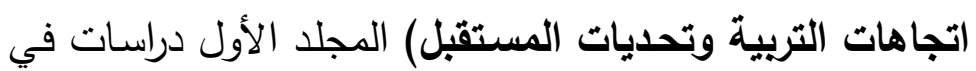

$$
\text { التربية الإسلامية، جامعة السلطان قابوس، }
$$

24) غاوجي، وهبي، الزكـاة وأحكامها وفق مذهب أبسي حنيفـة، (1985)

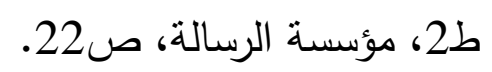

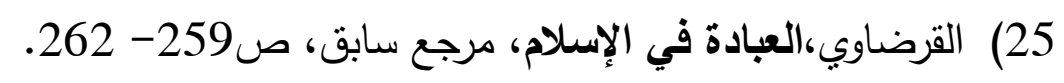

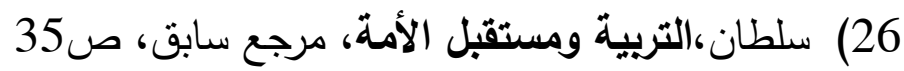

27) سنن ابن ماجه، كتاب الزكاة، باب صدقة الفطر حديث رقم (1827) 28) التسخيري، محمد وقانصوه محمود (1995)، الصوم معطياته وأحكامـه والروايات المشتركة فيه، ط1، دار التقلين، ص34. 29) سلطان،التربية ومستقبل الأمة، مرجع سابق،صائ 
مجلة الدراسات التريوية والانسانية ـ كلية التربية ـ جامعة دمنهور. المجلد التاسع - العدالأول - لسنة 2017

30) أبو زريق، أصول التربية الإسلامية، مرجع سابق، صابـأ51- 52.

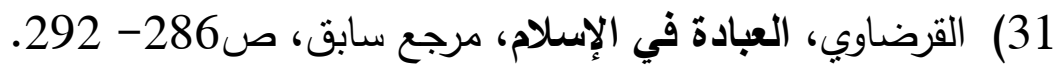

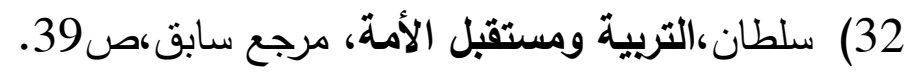

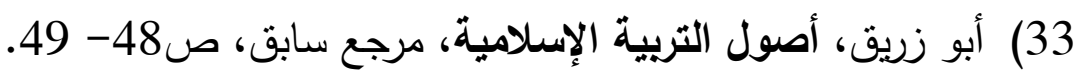

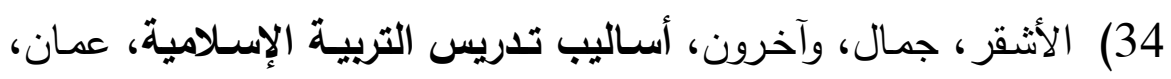

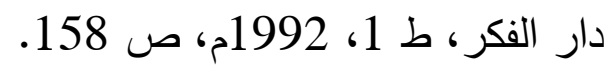

35) الأشقر ، جمال، أساليب تدريس التربية الإسلامية، صل صل 159. 


$$
\text { الأصل التعبدي للتربية الإسلامية وتطبيقاته التريوية د. ـولة أكرم جراح }
$$

